\title{
Inductance Calculation and New Modeling of a Synchronous Reluctance Motor Using Flux Linkages
}

\author{
Masayuki NashikiＭember（Denso corporation, m_nashiki@ybb.ne.jp) \\ Yoshimitu Inoue Non-member (Okuma corporation, y-inoue@gmx.okuma.co.jp) \\ Youichi Kawai Non-member (Okuma corporation, y-kawai@gmx.okuma.co.jp) \\ Shigeru Okuma Member (Nagoya University, okuma@okuma.nuee.nagoya-u.ac.jp)
}

Keywords: reluctance motor, flux barrier rotor, finite element method, inductance, flux linkage, motor control

New modeling of a synchronous reluctance motor SynRM which has non-linear magnetic characteristics is proposed. And a control method of the SynRM using the new model is developed.

The new model is based on the inductance data table or the flux linkage data table which is calculated with the flux linkages $\Psi_{d}\left(i_{d}, i_{q}\right), \Psi_{q}\left(i_{d}, i_{q}\right)$ of the SynRM at each current $\left(i_{d}, i_{q}\right)$. Detailed calculation method of the inductances is described in this paper. The calculated torque $T_{A}$ with the inductance data table is compared with the FEM torque $T_{f e m}$ and the difference is less than $5 \%$ at the rated torque. Therefore the accuracy of the new model is certified. Fig. 1 shows the inductances of the SynRM. Fig. 2 shows a sample of the flux linkage data table. Fig. 3 shows torque $T_{A}$ and $T_{f e m}$.

The same method is applicable to an interior permanent magnet synchronous motor IPMSM.

$$
\begin{array}{r}
T=P_{n}\left(L_{d}-L_{q}\right) i_{q} i_{d} \\
=P_{n}\left(\Psi_{d} i_{q}-\Psi_{q} i_{d}\right) \\
\Psi_{d}=L_{d} i_{q}, \quad \Psi_{q}=L_{q} i_{q}
\end{array}
$$

\begin{tabular}{|c|c|c|c|c|}
\hline $\bar{q}_{q} i_{d}$ & $i_{d 1}$ & $i_{d 2}$ & $\cdots \quad i_{d m}$ & $i_{d A}$ \\
\hline$i_{q 1}$ & $\psi_{d 11}, \psi_{q 11}$ & $\psi_{d 21}, \psi_{q 21}$ & $\cdots \psi_{d m t}, \psi_{q m 1} \cdots$ & $\psi_{d A 1}, \psi_{q A 1}$ \\
\hline$i_{q 2}$ & $\psi_{d 12}, \psi_{q 12}$ & $\psi_{d 22}, \psi_{q 22}$ & $\ldots \psi_{d m 2}, \psi_{q m 2} \ldots$ & $\psi_{d A 2}, \psi_{q A 2}$ \\
\hline $\begin{array}{c}i_{q n} \\
\vdots\end{array}$ & $\begin{array}{c}\vdots \\
\psi_{d l n}, \psi_{q 1 n} \\
\vdots\end{array}$ & $\begin{array}{c}\vdots \\
\psi_{d 2 n}, \psi_{q 2 n} \\
\vdots\end{array}$ & $\begin{array}{c}\vdots \\
\ldots \psi_{d m n}, \psi_{q m n} \ldots \\
\vdots\end{array}$ & $\begin{array}{c}\vdots \\
\psi_{d A n}, \psi_{q A n} \\
\vdots\end{array}$ \\
\hline$i_{q B}$ & $\psi_{d \mid B}, \psi_{q 1 B}$ & $\psi_{d 2 B}, \psi_{q 2 B}$ & $\ldots \psi_{d m B}, \psi_{q m B} \ldots$ & $\psi_{d A B}, \psi_{q A B}$ \\
\hline
\end{tabular}

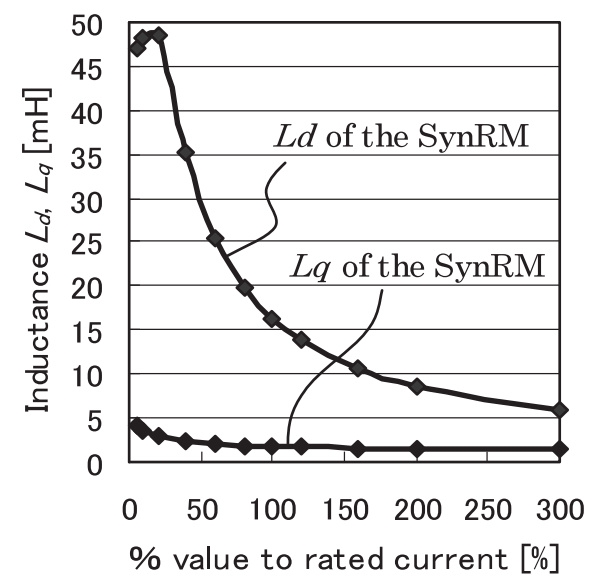

Fig. 1. Inductances of the SynRM (FEM)

Fig. 2. Data table of flux linkages
The high performance motor control is realized, because the exact current commands $\left(i_{d}, i_{q}\right)$, the exact voltage feed-foward commands $\left(F F_{d}, F F_{q}\right)$ and the adaptive current loop gain $\left(G_{d}, G_{q}\right)$ are obtained using the FEM data of the motor. Fig. 4 shows a block diagram of motor control. $\left(F F_{d}, F F_{q}\right)$ means $\left(v_{d}, v_{q}\right)$ and equations (6), (7) shows $\left(G_{d}, G_{q}\right)$ as follows.

$$
\begin{aligned}
{\left[\begin{array}{c}
v_{d} \\
v_{q}
\end{array}\right] } & =\left[\begin{array}{cc}
R+p L_{d} & -\omega L_{q} \\
\omega L_{d} & R+p L_{q}
\end{array}\right]\left[\begin{array}{l}
i_{d} \\
i_{q}
\end{array}\right] \ldots \ldots \\
& =\left[\begin{array}{cc}
p & -\omega \\
\omega & p
\end{array}\right]\left[\begin{array}{l}
\Psi_{d} \\
\Psi_{q}
\end{array}\right]+\left[\begin{array}{cc}
R & 0 \\
0 & R
\end{array}\right]\left[\begin{array}{l}
i_{d} \\
i_{q}
\end{array}\right] \ldots \ldots \ldots \ldots \ldots \ldots \ldots \ldots \ldots \ldots \ldots \ldots \ldots \ldots \ldots \ldots
\end{aligned}
$$

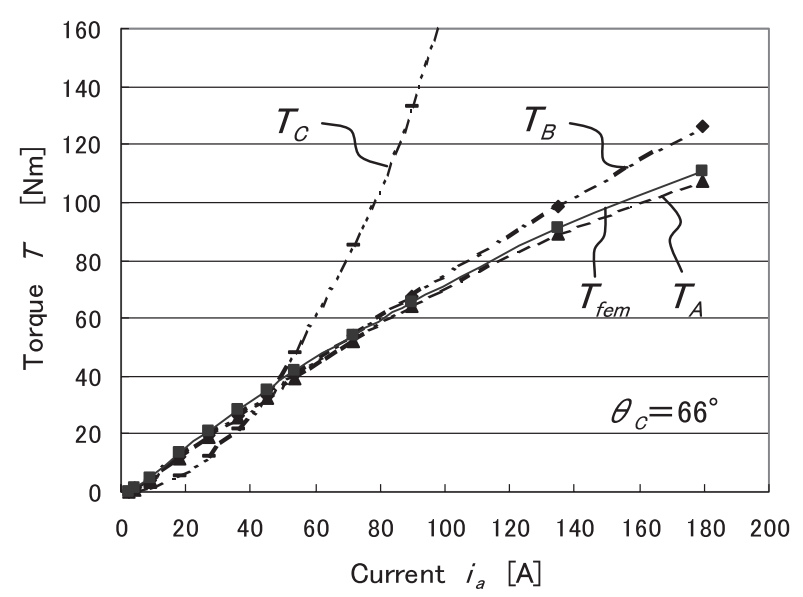

Fig. 3. Torque $T$ versus Current $i_{a}$ of the SynRM (FEM)

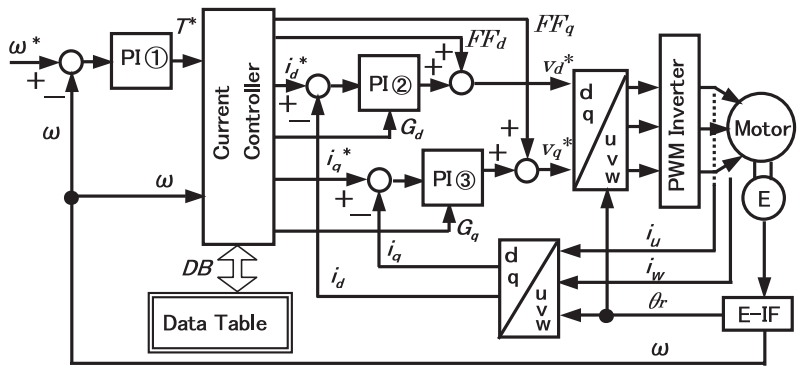

Fig. 4. Block diagram of motor control 


\title{
シンクロナスリラクタンスモータの磁束鎖交数を用いた インダクタンス算定法とモデル化の提案
}

\author{
正 員 梨木 政行* 非会員 井上 芳光** \\ 非会員 川井 庸市** 正 員 大熊＼cjkstart繁***
}

\author{
Inductance Calculation and New Modeling of a Synchronous \\ Reluctance Motor Using Flux Linkages \\ Masayuki Nashiki*, Member, Yoshimitu Inoue**, Non-member, \\ Youichi Kawai**, Non-member, Shigeru Okuma***, Member
}

\begin{abstract}
New modeling of a synchronous reluctance motor SynRM which has non-linear magnetic characteristics is proposed. And a control method of the SynRM using the new model is developed. The new model is based on the inductance data table or the flux linkage data table which is calculated with the flux linkages of the SynRM at each current $\left(i_{d}, i_{q}\right)$. Detailed calculation method of the inductances is described. The calculated torque $T_{A}$ with the inductance data table is compared with the torque $T_{f e m}$ which is calculated by FEM and the difference is less than $5 \%$ at the rated torque. Therefore the accuracy of the new model is certified. And the same method is applicable to an interior permanent magnet synchronous motor IPMSM. The high performance motor control is realized. The exact current commands $\left(i_{d}, i_{q}\right)$, the exact voltage feed-forward commands $\left(F F_{d}, F F_{q}\right)$ and the adaptive current loop gain $\left(G_{d}, G_{q}\right)$ are obtained using the FEM data of the motor.
\end{abstract}

キーワード：リラクタンスモータ, フラックスバリア形ロータ, 有限要素法, インダクタンス, 磁束鎖交数, 電動機制御

Keywords: reluctance motor, flux barrier rotor, finite element method, inductance, flux linkage, motor control

\section{1. まえがき}

スリット回転子を持つフラックスバリア型のシンクロナ スリラクタンスモータ (1) (9) $($ SynRM) は，永久磁石を使用 することなく製作できるので低コストであり，界磁弱め制 御による定出力制御が可能であるという特徴を持っている。 トルクリップルについては，回転子構造を改良することに より低減 (2)(3)(7)(8) が進められてきた。トルクの向上などの特 性改善については, 多くの回転子の改良に関する研究がな され，さらに，固定子の改良についても筆者らの研究がな され, 力率 $78 \%$ と従来型 SynRM の 1.6 倍の連続トルク出

\footnotetext{
*(株) デンソー 開発部

T 448-8661 愛知県刈谷市昭和町 1-1

Denso Co., Ltd.

1-1, Showa-cho Kariya, Aichi 448-8661

**オークマ (株) 研究開発部

T 480-0193 愛知県丹羽郡大口町下小口 5-25-1

Okuma Co., Ltd.

5-25-1, Simooguchi, Oguti-cho Niwa-gun, Aichi 480-0193

*** 名古屋大学

干 464-8603 名古屋市千種区不老町

Nagoya University

Furo-cho Chikusa-ku, Nagoya 464-8603
}

力の SynRM が示された ${ }^{(4)}$ 。

しかし，筆者らの改良電動機を含め，一般的にSynRM の磁気特性は透磁率の变化, 磁気飽和の非線形問題があり, $\mathrm{d}$ 軸インダクタンス $L_{d}, \mathrm{q}$ 軸インダクタンス $L_{q}$ の值を一定 值の電動機パラメータとして扱うことは困難であるという 問題がある。また, $L_{d}, L_{q}$ は $\mathrm{d}, \mathrm{q}$ 軸の電流 $i_{d}, i_{q}$ の相互の 干渉があり, $\mathrm{q}$ 軸電流 $i_{q}$ の時の $\mathrm{q}$ 軸インダクタンス $L_{q}$ が $\mathrm{d}$ 軸電流 $i_{d}$ の值より変化するという問題がある。これらの問 題を解決するために SynRM のインダクタンス $L_{d}, L_{q}$ につ

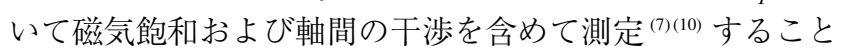
は可能であるが, 電動機の全動作領域について正確かつ詳 細に測定することは困難である。なお, SynRM の電流 $i_{d}$, $i_{q}$ の值によって変化する非線形なインダクタンス $L_{d}, L_{q}$ を 非線形有限要素法 FEM の解析デー夕から求める具体的な 方法, および, そのインダクタンス $L_{d}, L_{q}$ の精度を電動機 例で検証した例は報告されていない。

また，SynRM の磁気的な非線形性を含めた制御につい

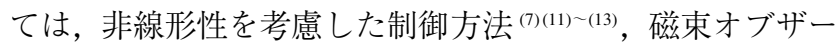
バを使用して磁気的な非線形性を補償する制御方法 ${ }^{(7)(11)(13)}$, 軸間の磁気的な相互干渉を補償した非干渉制御方法 ${ }^{(7)(12)}$ 等 が報告されている。しかし，補償制御の精度の問題，遅れ 
要素を含むことによる応答性の問題, 制御の複雑化による 制御装置の高コスト化の問題などがある。

本論文では，磁気的に非線形な SynRM の制御での問題 について検討し，正確な制御を実現するためには各動作点 $\left(i_{d}, i_{q}\right)$ における正確なインダクタンス $L_{d}\left(i_{d}, i_{q}\right), L_{q}\left(i_{d}, i_{q}\right)$ を得ることが必要であることを示す。そして，非線形有限 要素法 (FEM) で得たデータからそのインダクタンス $L_{d}$, $L_{q}$ を正確に求める具体的な方法を示す。

次に，著者らが改良開発した SynRMへその方法を適用 して電動機パラメータ $L_{d}, L_{q}$ を決定し, そのパラメータで 表現されるトルクと FEM で求めたトルクとの誤差が 5\%以 下であることを示す。なお，回転子内部に永久磁石を配置 した電動機構成であっても, 永久磁石の有無を意識するこ となく，同じアルゴリズムで電動機モデルを扱える。

さらに，電動機制御の新しい状態変数決定法と制御パラ メータ決定法を提案する。それは, 電動機の FEM のデー 夕を使用して磁束鎖交数 $\Psi_{d}\left(i_{d m}, i_{q n}\right), \Psi_{q}\left(i_{d m}, i_{q n}\right)$ のデータ テーブルを作成し，電動機を制御するものである。この方 法によれば, 非線形磁気特性, 磁気飽和に対して正確な電 動機情報に基づいて制御できるので, 精度と応答性が期待 できる

以下，第 2 章ではSynRM の特性と制御における問題を 示す。第 3 章では動作点におけるインダクタンス $L_{d}, L_{q}$ を 求める方法を示す。第 4 章では SynRM の具体例について の第 3 章の方法のトルクによる検証, SynRM に磁石を内 蔵した IPMSM のトルクによる検証， d, q 軸を回転移動さ せた場合のトルクによる検証を示す。第 5 章では磁束鎖交 数 $\Psi_{d}\left(i_{d m}, i_{q n}\right), \Psi_{q}\left(i_{d m}, i_{q n}\right)$ を用いた電動機モデルと電動機 制御法を提案する。第 6 章はまとめである。

\section{SynRM の制御における問題}

筆者らが直面した SynRM の制御上の問題を磁気非線形 性に着目して示す。

〈2・1〉SynRM の構成筆者らは, 先に, 回転子と固 定子の両方を改良したSynRM を試作し報告した ${ }^{(4)}$ 。図 1(a) は従来電動機の横断面図, 図 1(b) は改良電動機の横断面図 である。表 1 はその諸定数である。この SynRM の構成概 略は，(a) 固定子の歯の先端部を圧粉磁心で製作した分割コ アとして巻線の挿入を容易にし, 巻線の占積率向上, コイル エンド部の短縮を実現，(b) 固定子と回転子間のエアギャッ プ短縮による $L_{d}$ の向上, (c) 回転子の電磁鋼板 20 枚に 1 枚の割合で非磁性体であるステンレス板を挿入し，軸方向 相互に接着剂で固定することにより，回転子内部の細い磁 路間のつなぎ部を排除し， q 軸インダクタンス $L_{q}$ を低減し ている。その結果, 図 2 に示すように, 定格電流近傍にお ける突極比 $L_{d} / L_{q}$ を約 9 とし, トルクは従来電動機比 1.6 倍の值を得ることができた。

〈2・2〉SynRM の問題【しかし, 図 2 に示すインダク タンス特性は電流により大きく変化し非線形な特性である ため, 次に示すいくつかの問題がある。

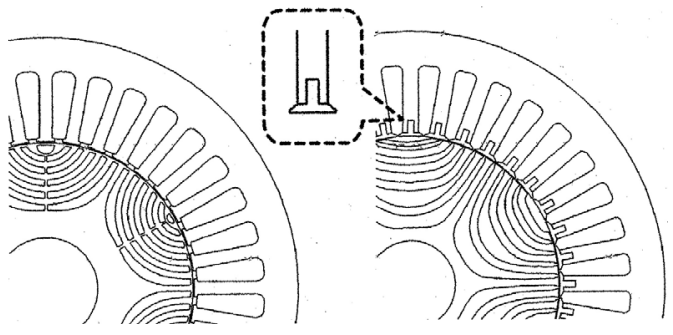

(a) Conventional motor

(b) Improved motor

図 1 SynRM の横断面図

Fig. 1. Cross sectional view of the SynRM.

表 1 SynRM のパラメータ

Table 1. SynRM parameters.

\begin{tabular}{|l|c|c|}
\hline \multicolumn{1}{|c|}{ Parameters } & $\begin{array}{c}\text { Conventional } \\
\text { motor }\end{array}$ & $\begin{array}{c}\text { Improved } \\
\text { motor }\end{array}$ \\
\hline Phase, Pole & 3 phase, 6 pole & 3 Phase, 6 pole \\
\hline Slot number & 36 slots & 36 slots \\
\hline Stator outer dia. & $\phi 172 \mathrm{~mm}$ & $\phi 172 \mathrm{~mm}$ \\
\hline Partial teeth & no & 36 pieces \\
\hline Air gap & $0.3 \mathrm{~mm}$ & $0.13 \mathrm{~mm}$ \\
\hline Rotor outer dia. & $\phi 100 \mathrm{~mm}$ & $\phi 100 \mathrm{~mm}$ \\
\hline Outer bridge & $0.5 \mathrm{~mm}$ & $0 \mathrm{~mm}$ \\
\hline Inner bridge & $0.5 \sim 1 \mathrm{~mm}$ & $0 \mathrm{~mm}$ \\
\hline Core length & $78 \mathrm{~mm}$ & $95 \mathrm{~mm}$ \\
\hline Rated torque & $15.7 \mathrm{Nm}$ & $25.7 \mathrm{Nm}$ \\
\hline Rated current $i_{d}$ & $19.5 \mathrm{~A}$ & $16 \mathrm{~A}$ \\
\hline Rated current $i_{q}$ & $38.2 \mathrm{~A}$ & $36 \mathrm{~A}$ \\
\hline
\end{tabular}

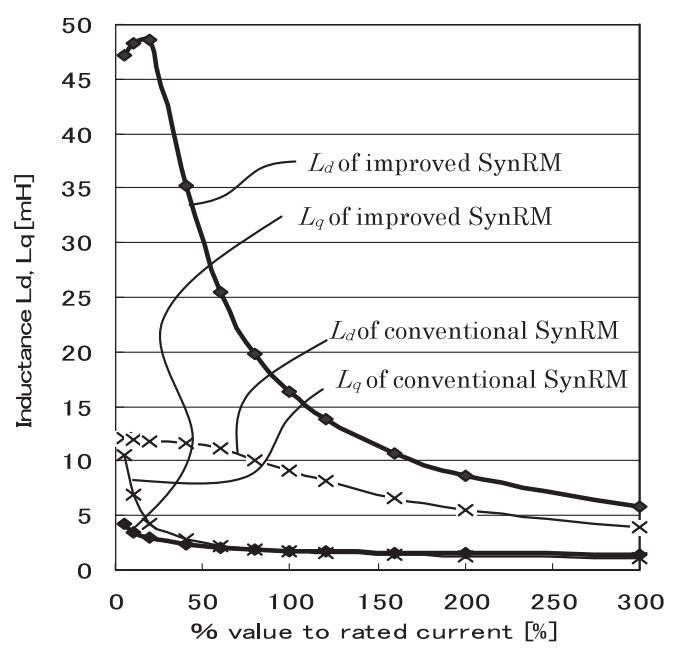

図 2 インダクタンス $L_{d}, L_{q}(\mathrm{FEM})$

Fig. 2. Inductance $L_{d}, L_{q}$ (FEM).

(1) 図 3 の電動機制御ブロックダイアグラムの例におい て, 高精度・高応答の用途では, トルク指令 $T^{*}$ に対 する電流指令值 $i_{d}^{*}$, $i_{q}^{*}$, 電圧のフィードフォワード量 $F F_{d}, F F_{q}$, 電流制御ループゲイン定数 $G_{d}, G_{q}$ の正確 な值が必要であるため, 調整要素が多くなるなど, 調 整機能が複雑化する。

(2) SynRM のインダクタンス $L_{d}, L_{q}$, あるいは, 磁束 鎖交数 $\Psi_{d}, \Psi_{q}$ を FEM による解析データから求める 手法が明確でない。また, そのインダクタンス $L_{d}, L_{q}$ 


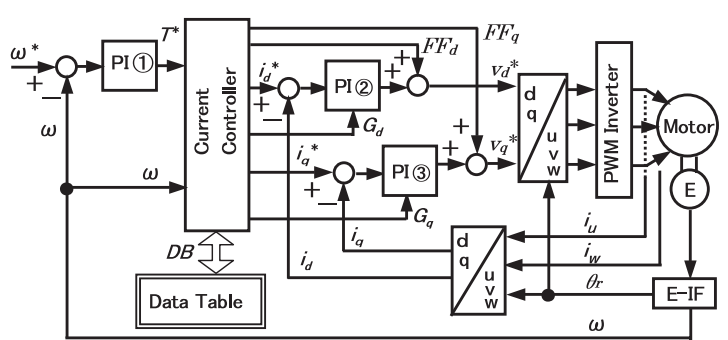

図 3 電動機制御のブロックダイアグラム

Fig. 3. Block diagram of motor control.

がトルク $T$ などの電動機特性をどの程度正確に表現で きるのかが検証されていない。

例えば，精密な工作機械などの制御においては，小トル ク領域で精密位置決めを行うことが多々あり，大電流領域 で過電流とならないように電流制御ループゲイン $G_{d}, G_{q}$ を設定すると，小電流領域では $L_{d}, L_{q}$ が数倍大きくなるた めゲインが不足して応答性が劣化する問題がある。

また，高速回転領域での界磁弱めによる定出力制御を行 う場合, 電源電圧の飽和を回避するための調整, 電流の安 定性を確保する調整が複雑化する。

\section{3. 動作点のインダクタンス $L_{d}\left(i_{d}, i_{q}\right), L_{q}\left(i_{d}, i_{q}\right)$ を求める方法}

本研究では，高い精度で得られる FEM の解析デー夕を 効果的に活用することを考える。

SynRMのトルク $T$ は(1) 式なので, インダクタンス $L_{d}, L_{q}$ は重要なパラメータである。しかし, 前記のように, SynRM のインダクタンス $L_{d}, L_{q}$ は, 図 2 に示すように磁気飽和 を含む非線形な值を示し，かつ， d 軸と q 軸との相互干涉 もあるため, 複雑な值を示す。従って, 正確なトルクを計 算するためには，その動作点のインダクタンス $L_{d}, L_{q}$ ある いは磁束鎖交数 $\Psi_{d}, \Psi_{q}$ を正確に求める必要がある。

$$
\begin{aligned}
T & =P_{n}\left(L_{d}-L_{q}\right) i_{q} i_{d} \\
& =P_{n}\left(\Psi_{d} i_{q}-\Psi_{q} i_{d}\right)
\end{aligned}
$$

そこで, 電動機の FEM デー夕を使用してこの動作点のイン ダクタンス $L_{d}\left(i_{q}, i_{d}\right), L_{q}\left(i_{q}, i_{d}\right)$ および磁束鎖交数 $\Psi_{d}\left(i_{q}, i_{d}\right)$, $\Psi_{q}\left(i_{q}, i_{d}\right)$ を正確に求好方法を, 次の $(1) \sim(7)$ 項に具体 的に示す。

\section{（1）モータモデルと解析条件の設定}

モデル例として筆者らの開発した電動機を挙げ，説明す る。その SynRM のパラメータを表 1 に，6極 36 スロット の内の 2 極 12 スロットモデルを図 4 に示す。スロット部 にスロット番号を，その近傍に各巻線の $\mathrm{U}, \mathrm{V}, \mathrm{W}$ 相を， ステータ外周部にその他のスロット番号 13〜36 を付記す る。図 5 は，図4のモー夕の結線と配置関係をシンボル的 に表現した図である。なお，電流は 1 スロット内の巻き回 数を $N_{S}$ とすると，スロット(1)と(2には，それぞれ，U 相電 流 $i_{u} \times N_{S}$ の電流が流孔る。

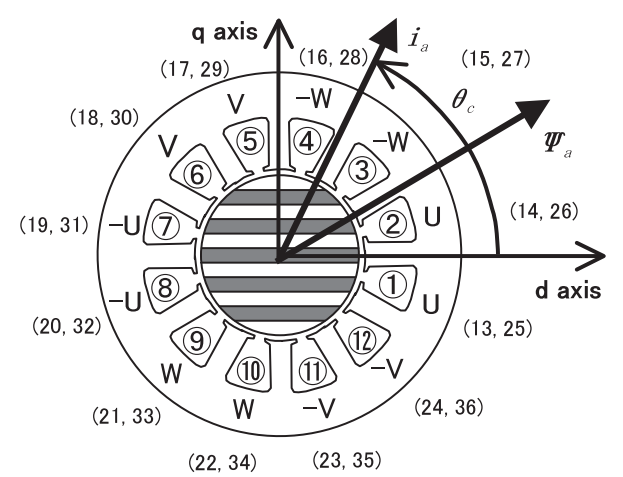

図 4 電動機のスロット配置

Fig. 4. Each slot position of the SynRM.

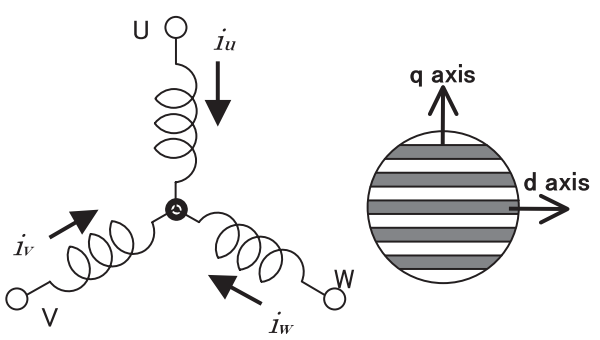

図 5 巻線の結線と回転子との位置関係

Fig. 5. Winding connections and relation to the rotor.

（2）固定座標系の $\mathrm{d} ， \mathrm{q}$ 軸電流成分の計算

評価する動作点における $\mathrm{d}, \mathrm{q}$ 軸の電流 $i_{d 1}, i_{q 1}$ を電流振 幅 $i_{a}$ と制御位相角 $\theta \mathrm{c}$ の值から求める。

$i_{d 1}=i_{a} \cdot \cos \theta \mathrm{c}, \quad i_{q 1}=i_{a} \cdot \sin \theta \mathrm{c}$.

次に, 固定座標系での 3 相電流振幅值に換算した電流成分 $i_{d 2}, i_{q 2}$ を求める。

$$
i_{d 2}=\sqrt{2 / 3} \cdot i_{d 1}, \quad i_{q 2}=\sqrt{2 / 3} \cdot i_{q 1}
$$

（3） U 相から V 相へ全電流が流れる位相の電流值に換 算

相電流が最大の点から位相が $30^{\circ}$ 進んだ電流值に換算し た $i_{d 3}, i_{q 3}$ を求める。

$$
i_{d 3}=\sqrt{3} / 2 \cdot i_{d 2}, \quad i_{q 3}=\sqrt{3} / 2 \cdot i_{q 2}
$$

（4）各コイルの鎖交磁束 $\phi_{\mathrm{n}}$

評価する電流振幅 $i_{a}$ と制御位相角 $\theta \mathrm{c}$ より図 4 に扔ける 3 相巻線電流 $i_{u}, i_{v}, i_{w}$ を換算する。

$$
\begin{aligned}
& i_{u}=\sqrt{2 / 3} \cdot i_{a} \cdot \sin \theta \mathrm{c} \ldots \ldots \ldots \\
& i_{v}=\sqrt{2 / 3} \cdot i_{a} \cdot \sin (\theta \mathrm{c}-2 \pi / 3) \\
& i_{w}=\sqrt{2 / 3} \cdot i_{a} \cdot \sin (\theta \mathrm{c}-4 \pi / 3)
\end{aligned}
$$

これらの 3 相電流を図 1(b) の電動機モデルへ通電した状態 で FEM 解析を行い, トルク $T_{1}$ と各巻線の鎖交磁束 $\phi_{1} \sim$ $\phi_{36}$ を単位厚さ $t_{0}$ 当たりの解析值として求める。なお, 解 析条件として, 回転子は図 4 の d, q 軸の回転位置に固定 ᄂ, 電流振幅 $i_{a}$, 電流位相角 $\theta_{c}$ の值は, 図 8 , 図 9 , 図 10 
等に示すそれぞれの值をとっている。ここで，前記鎖交磁 束は各巻線 Wn に沿ったベクトルポテンシャル $\boldsymbol{A}$ の積分值 として求められる。なお， 3 次元形状巻線の場合でも, 巻 線に沿ってベクトルポテンシャル $\boldsymbol{A}$ を積分して鎖交磁束を 求めることができる。

（5）磁束鎖交数 $\Psi_{d 3}, \Psi_{q 3}$ の計算

$\mathrm{d}$ 軸を向いた 2 相分の巻線の磁束鎖交数 $\Psi_{d 3}$ を求める。 スロット(9)，(11)，(11)，(12からスロット(3)，(4)，(5)，(6)へ (5) 式の $i_{d 3}$ が通電されていると想定している。

$$
\begin{aligned}
\Psi_{d 3}\left(i_{d 1}, i_{q 1}\right)= & \left\{\left(\phi_{9}-\phi_{3}\right)+\left(\phi_{10}-\phi_{4}\right)+\left(\phi_{11}-\phi_{5}\right)\right. \\
& \left.+\left(\phi_{12}-\phi_{6}\right)\right\} \times N_{S} \times t_{C} / t_{0} \times P n
\end{aligned}
$$

ここで， $N_{S}$ はスロットに巻回される巻き回数， $t_{C}$ はコ ア積厚, $P n$ は極対数 6/2=3である。

なお，トルクリップル低減対策のために，ロータ形状が各 磁極対ごとに異なる場合には，(9) 式と同様の計算を 36 久 ロット分行い，(9) 式から極対数 $P n$ を削除する必要がある。

同様に, $\Psi_{q 3}\left(i_{d 1}, i_{q 1}\right)$ を求める。スロット(1), (1), (2), (3) からスロット(6)，(7)，(8)，(9) (5) 式の $i_{q 3}$ が通電されてい ると想定している。

$$
\begin{aligned}
\Psi_{q 3}\left(i_{d 1}, i_{q 1}\right)= & \left\{\left(\phi_{12}-\phi_{6}\right)+\left(\phi_{1}-\phi_{7}\right)+\left(\phi_{2}-\phi_{8}\right)\right. \\
& \left.+\left(\phi_{3}-\phi_{9}\right)\right\} \times N_{S} \times t_{C} / t_{0} \times P n
\end{aligned}
$$

（6）固定座標系でのインダクタンス $L_{d 3}, L_{q 3}$ 図 5 の端子間インダクタンス $L_{d 3}, L_{q 3}$ を求める。

$$
\begin{aligned}
& L_{d 3}\left(i_{d 1}, i_{q 1}\right)=\Psi_{d 3}\left(i_{d 1}, i_{q 1}\right) / i_{d 3} \\
& L_{q 3}\left(i_{d 1}, i_{q 1}\right)=\Psi_{q 3}\left(i_{d 1}, i_{q 1}\right) / i_{q 3}
\end{aligned}
$$

(7) $\mathrm{d}, \mathrm{q}$ 軸のインダクタンス $L_{d}\left(i_{d 1}, i_{q 1}\right), L_{q}\left(i_{d 1}, i_{q 1}\right)$ $\mathrm{d}, \mathrm{q}$ 軸のインダクタンス $L_{d}, L_{q}$ はスター結線時の端子 間インダクタンスの最大值, 最小值の $1 / 2$ の值となる関係(7) から求める。

$$
\begin{aligned}
& L_{d}\left(i_{d 1}, i_{q 1}\right)=1 / 2 \times L_{d 3}\left(i_{d 1}, i_{q 1}\right) \\
& L_{q}\left(i_{d 1}, i_{q 1}\right)=1 / 2 \times L_{q 3}\left(i_{d 1}, i_{q 1}\right)
\end{aligned}
$$

なお, 前記手順で求められたインダクタンス $L_{d}\left(i_{d 1}, i_{q 1}\right)$, $L_{q}\left(i_{d 1}, i_{q 1}\right)$ の計算は, その表計算ソフトを準備しておけば, FEM 解析結果のデー夕を入力するだけで (3)〜 (14) 式を容 易に計算することができる。そして，各電流 $i_{d} ， i_{q}$ におけ るインダクタンス $L_{d}\left(i_{d 1}, i_{q 1}\right), L_{q}\left(i_{d 1}, i_{q 1}\right)$ を，例えば図 6 に 示すデータテーブルとして得ることができる。

\section{4. 動作点のインダクタンス $L_{d}\left(i_{d}, i_{q}\right), L_{q}\left(i_{d}, i_{q}\right)$ を用いて求めたトルク}

第 3 章に記述したインダクタンス算定方法で求めた $L_{d}\left(i_{d 1}, i_{q 1}\right), L_{q}\left(i_{d 1}, i_{q 1}\right)$ の妥当性について, 改良電動機のト

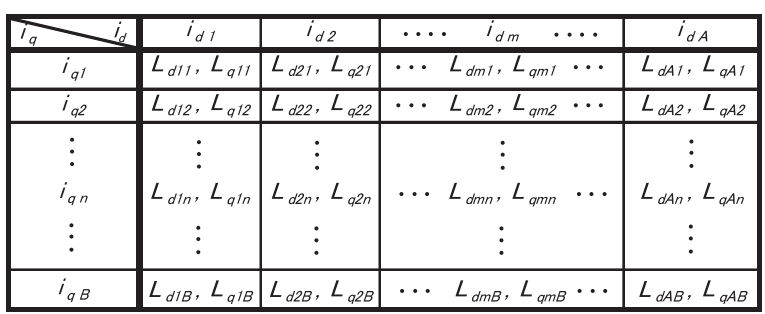

図 6 インダクタンス $L_{d}, L_{q}$ のデータテーブル例

Fig. 6. Data table of inductances.

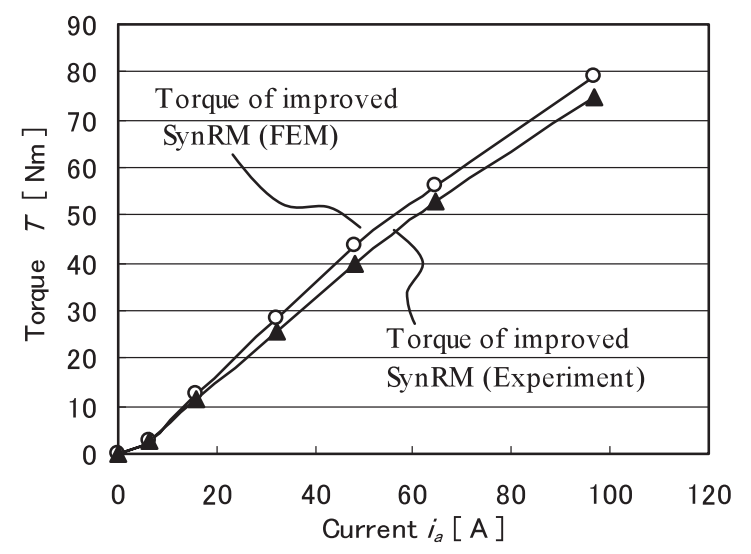

図 7 トルク $T$-電流特性

Fig. 7. Torque $T$ versus Current $i_{a}$.

ルク, 従来電動機のトルク, 永久磁石を内蔵した電動機の トルクの各例で検証する。また， d, q 軸座標の回転方向位 置を $30^{\circ}$ 変えた時のトルクについて比較し, インダクタン スとトルクの座標依存性を評価する。

なお，この第 4 章では, FEM で求めたトルク $T_{f e m}$ がほ ほ正しい值であると仮定し，トルクの検証值とする。信頼 のおける非線形有限要素法で求められるトルク精度は, 解 析対象モデルの形状精度, 材料特性と条件設定等が正確で あれば十分に信頼に足るものであることは周知である。ま た, 筆者らの先の報告 ${ }^{(4)}$ でも, 図 1(b) の電動機のトルクは, 図 7 に示すように, FEMのトルクと試作電動機の実測トル クとがほぼ一致することを確認している。横軸は電流振幅 值 $i_{a}$, 縦軸はトルク $T$ である。

$\langle\mathbf{4} \cdot \mathbf{1}\rangle$ インダクタンス $\boldsymbol{L}_{\boldsymbol{d}}, \boldsymbol{L}_{\boldsymbol{q}}$ から計算されるトルク 図 1(b) の改良SynRM のトルク特性を図 8 に示す。 $T_{f e m}$ は FEM で求めたトルク， $T_{A}$ は第 3 章で示した方法で求め た動作点のインダクタンス $L_{d}\left(i_{d 1}, i_{q 1}\right), L_{q}\left(i_{d 1}, i_{q 1}\right)$ より (1) 式で計算したトルク， $T_{B}$ は $\mathrm{d}$ 軸と $\mathrm{q}$ 軸でそれぞれに単独に 電流と磁束鎖交数を求めて得たインダクタンス $L_{d}\left(i_{d 1}, 0\right)$, $L_{q}\left(0, i_{q 1}\right)$ より (1) 式で計算したトルク, $T_{C}$ は連続定格電流 における $L_{d}, L_{q}$ を全電流領域で比例定数として扱って (1) 式で計算したトルクである。

各トルク $T_{A}, T_{B}, T_{C}$ を FEM トルク $T_{f e m}$ と比較して 各インダクタンスの精度を検証する。トルク $T_{A}$ は $T_{f e m}$ と ほぼ一致した值であり, 電流 $i_{a}=180 \mathrm{~A}$ の時の誤差でも $3.3 \%$ とさい值である。 $\mathrm{d}$ 軸と $\mathrm{q}$ 軸との相互干渉を無視し 


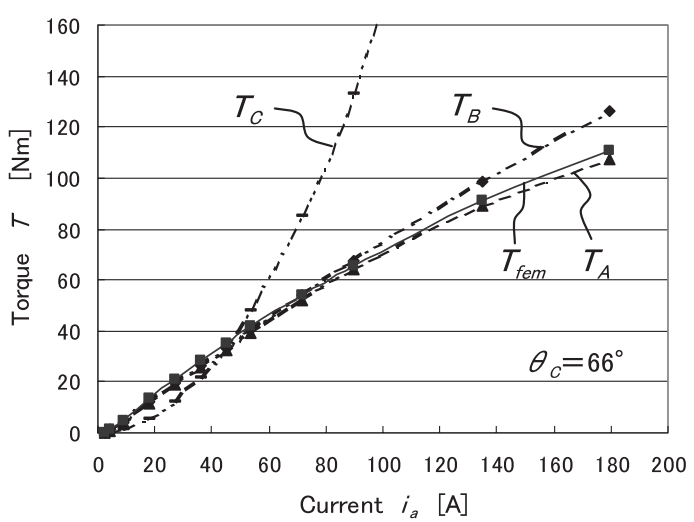

図 8 改良型 SynRM のトルク特性（FEM） Fig. 8. Torque $T$ versus Current $i_{a}$ of the SynRM (FEM).

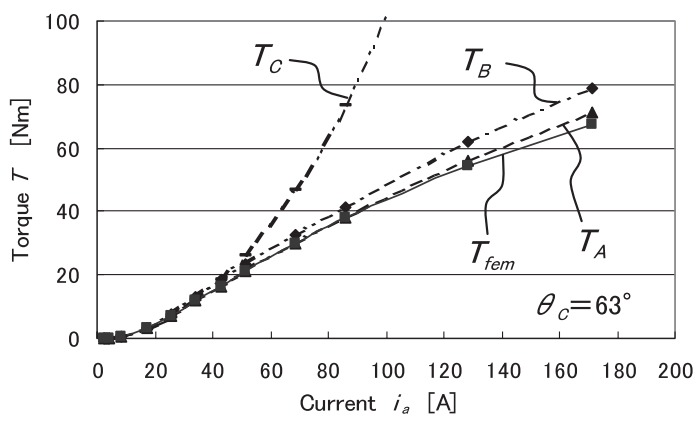

図 9 従来型 SynRM のトルク特性 (FEM)

Fig. 9. Torque $T$ versus Current $i_{a}$ of the SynRM (FEM).

た $T_{B}$ はやや誤差が大きく，電流 $i_{a}=180 \mathrm{~A}$ の時の誤差が $13.9 \%$ となった。インダクタンス $L_{d}, L_{q}$ を定数として扱う $T_{C}$ は, 特に電流の大きな領域では実際のトルクとはかけ離 れた值となることが分かる。

次に，図 1(a)に示す従来電動機の同様なトルク特性を 図 9 に示す。インダクタンスから計算されるトルク $T_{A}$ は $T_{f e m}$ とほぼ一致した值であり, 電流 $i_{a}=170 \mathrm{~A}$ の時の誤差 でも $5.7 \%$ とさい值である。改良電動機に比較して回転 子形状，インダクタンスが異なるが，良く一致している。 $\mathrm{d}$ 軸と $\mathrm{q}$ 軸との相互干渉を無視した $T_{B}$ はやや誤差が大きく, 電流 $i_{a}=180 \mathrm{~A}$ の時の誤差が $17.1 \%$ となった。

$\langle\mathbf{4 \cdot 2 \rangle}$ 界磁弱め領域におけるトルク 次に, 改良電動 機の界磁弱め領域について，前記方法で求めたインダク夕 ンスから計算されるトルクの精度について検証する。図 10 は横軸を電流位相角 $\theta_{c}$, 縦軸をトルク $T$ とし, $\mathrm{q}$ 軸電流 $i_{q}=10 \mathrm{~A} ， 20 \mathrm{~A} ， 30 \mathrm{~A} ， 40 \mathrm{~A}$ をパラメータとした特性で ある。インダクタンスから (1) 式で計算したトルク $T_{25 L}$, $T_{50 L}, T_{75 L}, T_{100 L}$ は, $\mathrm{d}$ 軸電流の微少な領域においても, FEM トルク $T_{25 \mathrm{fem}}, T_{50 \mathrm{fem}}, T_{75 \mathrm{fem}}, T_{100 \mathrm{fem}}$ に近い值が得 られており，各動作点において正確なインダクタンスが得 られていることが解る。

$\langle 4 \cdot 3\rangle$ IPMSM の磁束鎖交数 $\boldsymbol{\Psi}_{\boldsymbol{d}}, \boldsymbol{\Psi}_{\boldsymbol{q}}$ から計算される トルク図 11 に示す $\mathrm{NdFeB}$ 系の永久磁石を内蔵する電

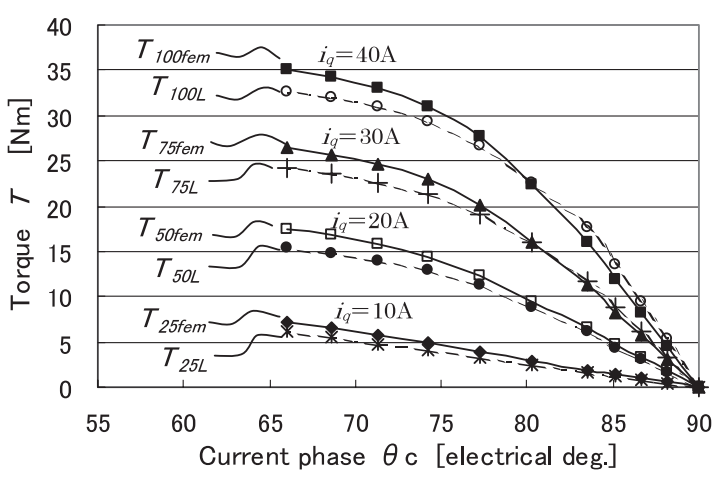

図 10 界磁弱め領域のトルク特性 (FEM)

Fig. 10. Torque $T$ versus Current $i_{a}$ of the SynRM (FEM).

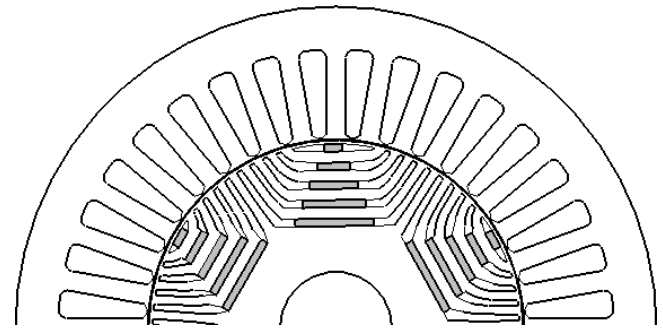

図 11 永久磁石を内蔵した SynRM

Fig. 11. SynRM with permanent magnets in the rotor.

動機の例について, 第 3 章で示した方法でのトルク計算值 $T_{A}$ を検証する。通常, 永久磁石を使用した電動機の電圧方 程式は，電流に起因する電圧成分と磁石に起因する電圧成 分とを分けて表現することが多いが，(2)式のように，トル クは電流ベクトル $\boldsymbol{i}_{a}$ と磁束鎖交数ベクトル $\Psi_{a}$ の外積なの で, 磁石に起因する磁束とその他の磁束とを分離すること なく取り扱うこともできる。ただしその時は， d, q 軸の全 ての磁束鎖交数 $\left(\Psi_{d}, \Psi_{q}\right)$ と電流 $\left(i_{d}, i_{q}\right)$ の比をインダ クタンス $\left(L_{d}, L_{q}\right)$ であると仮定して (1) 式よりトルク $T$ を求めることにする。この条件で，第 3 章で示した方法で 求めたインダクタンスから計算されるトルク $T_{A}$ は, 図 12 に示すように， $T_{f e m}$ とほぼ一致した值であり，最大誤差で も $2.9 \%$ とさい值となった。

$\langle\mathbf{4} \cdot \mathbf{4}\rangle$ 回転子の d, q 軸の回転方向位置を $30^{\circ}$ 変えた場 合のトルク 第 3 章で示した方法の妥当性を検証する一 つの方法として，d，q 軸座標を図 4 の座標から図 13 に示 す $\mathrm{d}_{1}, \mathrm{q}_{1}$ 軸座標に回転方向位置を $30^{\circ}$ 変えてみる。図 $1(\mathrm{~b})$ の改良電動機について, この $\mathrm{d}_{1}, \mathrm{q}_{1}$ 座標で各軸の電流成 分, 磁束成分を第 3 章の方法で求め，(1) 式で計算したトル クを図 14 に示す。新しい座標でのインダクタンスから計 算したトルク $T_{A C W}$ は $T_{f e m}$ とほぼ一致した值であり, 電流 $i_{a}=180 \mathrm{~A}$ の時の誤差でも $2.7 \%$ とさい值となった。な お, 図 8 の回転しない座標で求め, 計算したトルク $T_{A}$ を 図 14 に書くと $T_{A C W}$ と殆ど同じ值であり，重なった。

この結果，SynRMにおいて正確なインダクタンスを求 めることができれば，座標軸を回転させても大きなトルク 


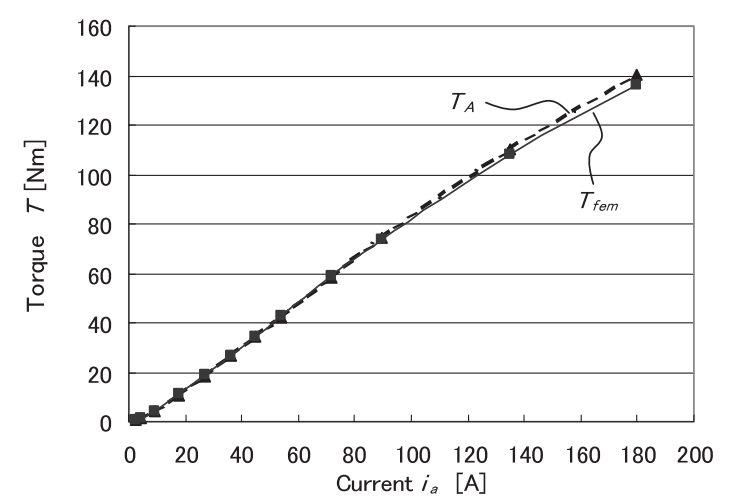

図 12 永久磁石内蔵の SynRM のトルク特性 (FEM)

Fig. 12. Torque $T$ versus Current $i_{a}$ of the SynRM (FEM).

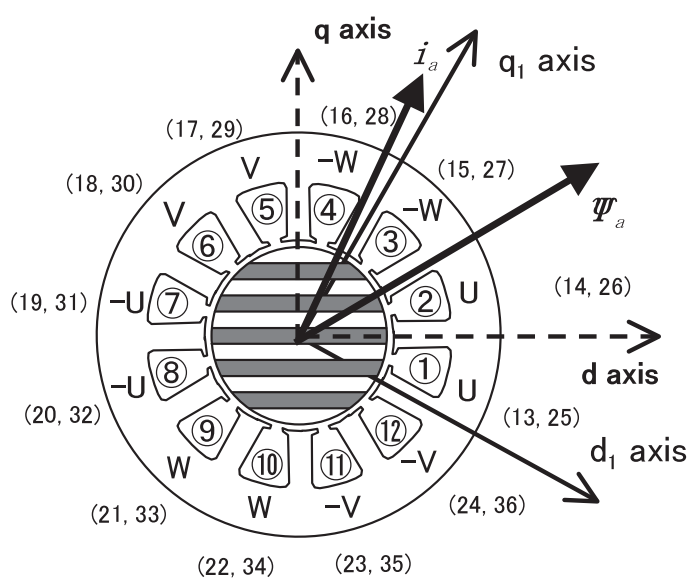

図 $13 \mathrm{CW}$ へ $30^{\circ}$ 座標軸を回転した $\mathrm{d}_{1} \mathrm{q}_{1}$ 座標

Fig. 13. Each slot position of the SynRM.

誤差が発生しないことを検証できた。

この時, $\mathrm{d}_{1}, \mathrm{q}_{1}$ 軸の磁束鎖交数 $\left(\Psi_{d 1}, \Psi_{q 1}\right)$ と電流 $\left(i_{d 1}\right.$, $\left.i_{q 1}\right)$ との比を $\left(L_{d 1}, L_{q 1}\right)$ とした特性を図 15 に示す。この 例では, $\mathrm{q}_{1}$ 軸電流 $i_{q 1}$ により $\mathrm{d}_{1}$ 軸の磁束鎖交数 $\Psi_{d 1}$ の大半 が $\mathrm{d}_{1}$ 軸電流 $i_{d 1}$ とは逆方向に発生するため, $L_{d 1}$ が負の值 になっている。しかし，この $L_{d 1}$ は電流べクトル $\boldsymbol{i}_{a}$ と磁束 鎖交数べクトル $\Psi_{a}$ の外積計算の一部の值としては正しく, (1) 式の答であるトルク $T_{A C W}$ は図 14 に示すように正確で ある。

5. 磁束鎖交数 $\boldsymbol{\Psi}$ を使用したデータテーブルによる 電動機モデルと制御法

FEM 解析結果より求めたデータテーブルを活用する制御 法について考察する。そして, 電動機モデルが正確になっ て，構成が簡素になることを示す。

$\langle\mathbf{5} \cdot \mathbf{1}\rangle$ 磁束鎖交数 $\boldsymbol{\Psi}_{d}\left(i_{d}, i_{q}\right), \boldsymbol{\Psi}_{q}\left(i_{d}, i_{q}\right)$ のデータテーブ ルを使用した電動機モデル 図 8 から図 15 に示したよ うに，高調波を含むFEM デー夕を使用して，正弦波理論 でかつ集中定数的扱いをするインダクタンス $L_{d}, L_{q}$ ある いは磁束鎖交数 $\Psi_{d}, \Psi_{q}$ を第 3 章の方法で求め，(1) 式ある

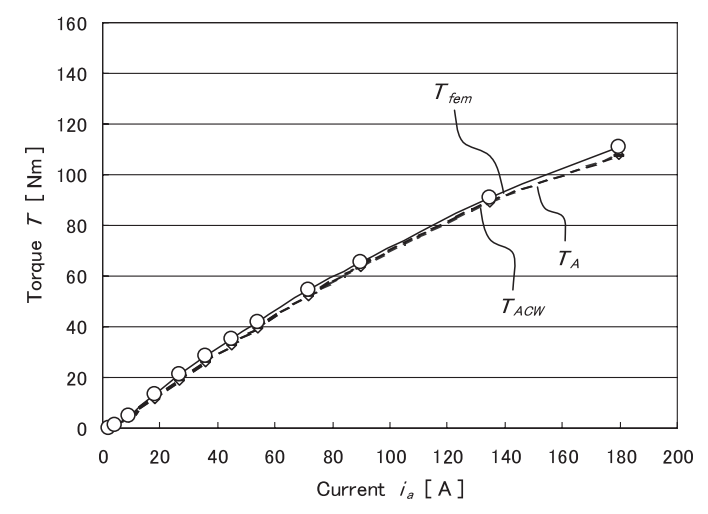

図 14 座標軸を回転したトルク特性（FEM）

Fig. 14. Torque $T$ versus Current $i_{a}$ of a SynRM (FEM).

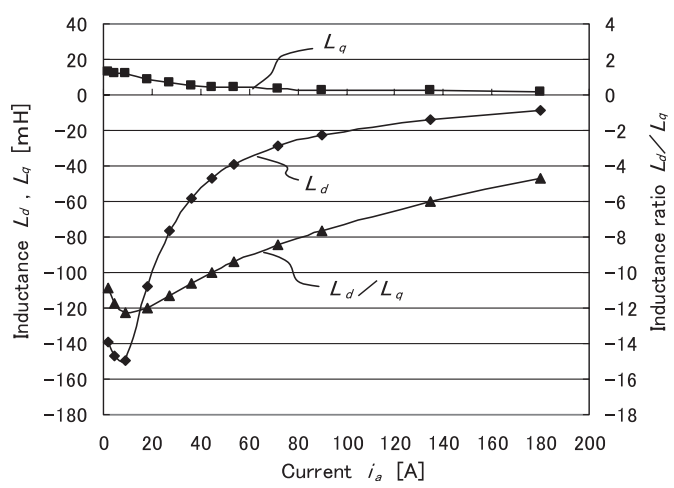

図 15 座標軸を回転したインダクタンス（FEM）

Fig. 15. Inductances in the rotated axes (FEM).

いは (2) 式でトルク $T_{A}$ を計算し, 正確な值が得られること を検証した。

現在, 良く使用されている電動機モデル，その電圧方程 式等は (15) 式に示すように, 電動機の磁束鎖交数 $\Psi$ がイ ンダクタンス $L$ と電流 $i$ で表現されている。図 16 の破線 で囲まれた電動機の模式図における $\Psi=L \times i$ の関係であ る。しかし，インダクタンス $L$ が非線形で，さらには永久 磁石を含む特性を考える時, 磁束鎖交数 $\Psi$ と電流 $i$ で表現 する方が汎用的であるとも考えられる。また，電動機の各 動作点で特性が変化するので，この磁束鎖交数 $\Psi$ のデー夕 テーブルを使用した電動機のモデル化が，非線形な特性に も柔軟に対応でき適切であると考えられる。

なお，データテーブルの内容は FEM データから正確に, かつ，容易に作成することができる。また，図 16 において 破線で示される電動機の入力は電圧 $v$ と電流 $i$, 出力は回転 速度 $\omega$ とトルク $T$ である。

電動機を磁束鎖交数 $\Psi$ で表現する方法は, $\Psi_{d}=L_{d} i_{d}$, $\Psi_{q}=L_{q} i_{q}$ と置き換えれば良く, データテーブルは図 6 か ら図 17 へ置き換えられる。電圧方程式は, 同様に, (15) 式 を(16) 式のように変更して表現できる。なお， $1 \mathrm{~kW}$ 以上 の容量の電動機で効率が $90 \%$ を超える場合, 抵抗值 R が相 対的に小さいので (16) 式の第 2 項を省略して (17) 式とし 


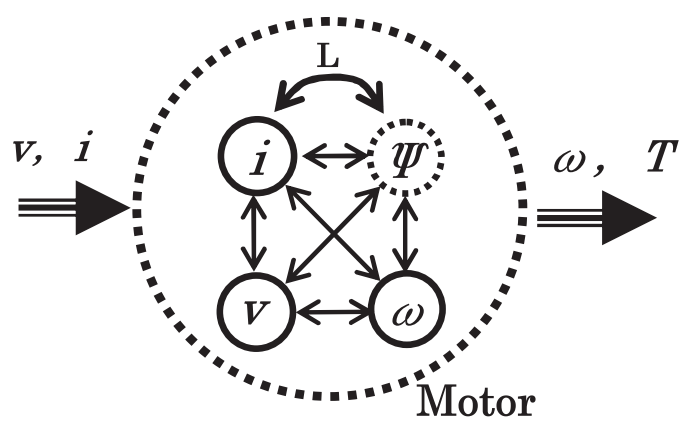

図 16 SynRM の模式図

Fig. 16. Explanation of motor construction.

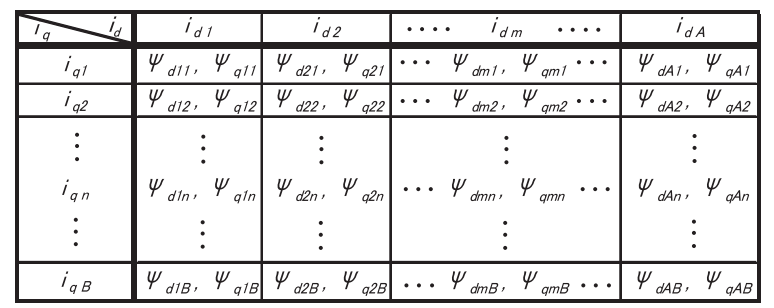

図 17 磁束鎖交数 $\Psi_{d}, \Psi_{q}$ のデータテーブル例

Fig. 17. Data table of flux linkages.

て簡素化して扱っても，制御的に影響が少ない場合もある。 また，トルク $T$ は (2) 式で表される。

$$
\begin{aligned}
{\left[\begin{array}{l}
v_{d} \\
v_{q}
\end{array}\right] } & =\left[\begin{array}{cc}
R+p L_{d} & -\omega L_{q} \\
\omega L_{d} & R+p L_{q}
\end{array}\right]\left[\begin{array}{l}
i_{d} \\
i_{q}
\end{array}\right] \ldots \ldots \\
& =\left[\begin{array}{cc}
p & -\omega \\
\omega & p
\end{array}\right]\left[\begin{array}{l}
\Psi_{d} \\
\Psi_{q}
\end{array}\right]+\left[\begin{array}{cc}
R & 0 \\
0 & R
\end{array}\right]\left[\begin{array}{l}
i_{d} \\
i_{q}
\end{array}\right] \ldots \\
& \fallingdotseq\left[\begin{array}{cc}
p & -\omega \\
\omega & p
\end{array}\right]\left[\begin{array}{l}
\Psi_{d} \\
\Psi_{q}
\end{array}\right] \ldots \ldots \ldots \ldots \ldots
\end{aligned}
$$

ベクトル図は図 18 のように変更して表現できる。なお， より厳密な電圧式が必要な場合は，鉄損および漏れインダ クタンス成分である漏れ磁束鎖交数 Yleak (16) 式に付 加した精密モデルとして表現することもできる(7)(14)。

このように，(2)，(16)〜(19) 式拈よび図 17 のデータテー ブル, 図 18 のベクトル図に示すように,インダクタンス $L_{d}, L_{q}$ を使用せず, 図 16 の電流 $i$, 電圧 $v$, 磁束鎖交数 $\Psi$, 回転数 $\omega$ で電動機を表現することもできる。

$\langle\mathbf{5} \cdot \mathbf{2}\rangle$ 電動機制御における電流指令值作成の例 次 に, 電動機の定トルク制御と定出力制御の場合の電流指令 值 $\left(i_{d}^{*}, i_{q}^{*}\right)$ を作成する方法の例について, 図 3 の電動機制御 のブロックダイアグラムに従って示す。

（1）トルク制御型の電流指令值作成法電動機制御 の具体例として, 主にトルク制御であって, 界磁弱め制御 を行わない場合について示す。この例では, 図 3 に示すエ ンコーダ $\mathrm{E}$ が回転子軸に連結され, 回転位置 $\theta_{r}$ および速 度 $\omega$ はそのインターフェイス E-IFにより得られるものと する。

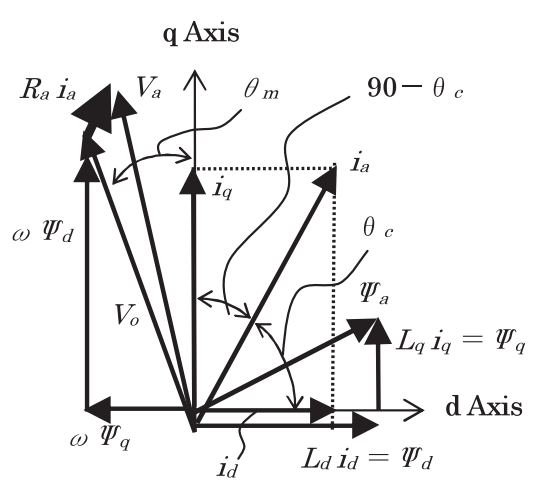

図 18 SynRM のベクトル図

Fig. 18. Vector diagram of SynRM.

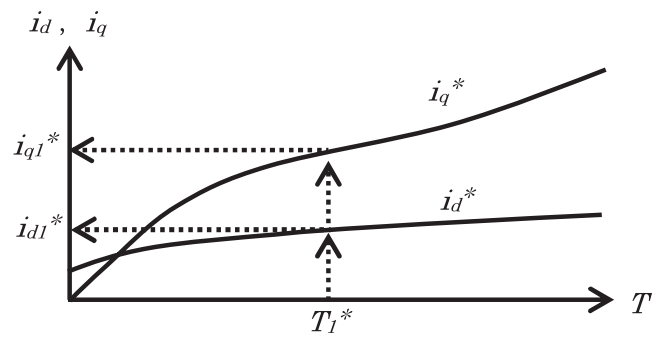

図 19 トルク指令 $T^{*}$ と電流指令 $i_{d}^{*}, i_{q}^{*}$ の例

Fig. 19. Current $i_{d}, i_{q}$ versus toruque $T$.

トルク指令 $T^{*}$ に対する電流指令 $\left(i_{d}^{*}, i_{q}^{*}\right)$ の決定方法とし て, 例えば, 図 17 のデータテーブルを元に, 図 19 のよう な電流特性をデータテーブル化して作成しておき, トルク 指令 $T_{1}^{*}$ に対する電流指令 $\left(i_{d 1}^{*}, i_{q 1}^{*}\right)$ の值を, 内挿計算し決定 する方法が考えられる。

なお，トルク $T$ は (2) 式で表され，電流值選択の自由度 がある。従って, 図 19 に示す特性の電流指令のデータテー ブルは, 例えば, 効率最優先の制御, $i_{d}$ を一定とする制御な ど目的に応じた電流指令テーブルを作成することができる。

（2）定出力制御型に扔ける電流指令值作成法 界磁 弱め制御による定出力制御に扮いても, 図 17 に示寸磁束 鎖交数のデータテーブルを使用して，トルク指令 $T^{*}$ に対 する電流指令值 $\left(i_{d}^{*}, i_{q}^{*}\right)$ を作成することができる。

ここで, 電動機の定出力制御は, 制御装置の電源電圧が 制限されるために必要となる制御法なので, 電源電圧の制 限に対応したデータテーブルを, 図 17 の磁束鎖交数のデー タテーブルから計算して作成することになる。具体的な例 として, 回転数 $\omega_{1}$ とトルク指令 $T_{1}^{*}$ とに対する電流指令 $\left(i_{d 1}^{*}, i_{q 1}^{*}\right)$ を図 20 に示すようなテーブルとして作成してお

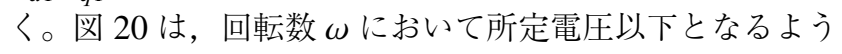
な電流指令 $\left(i_{d 1}^{*}, i_{q 1}^{*}\right)$ を決定できるようなデータテーブルで あって, 高速回転においては, 同時に電動機特性に応じた トルク制限も加えられることになる。そして, トルク指令 $T_{1}^{*}$, 回転数 $\omega$ 対する電流指令 $\left(i_{d 1}^{*}, i_{q 1}^{*}\right)$ の值を, テーブルか ら内挿計算して得ることができる。 


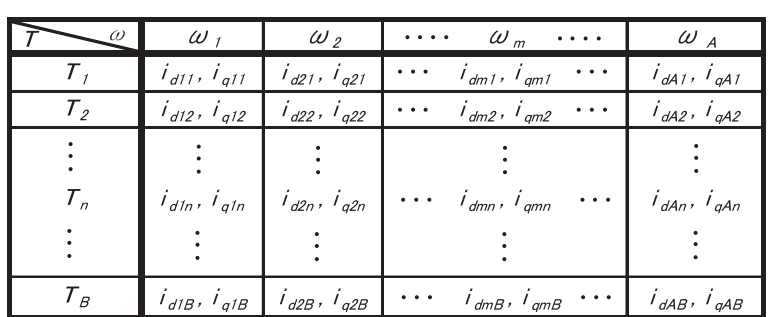

図 20 トルク指令 $T^{*}$ と回転数 $\omega$ と電流指令 $i_{d}^{*}, i_{q}^{*}$

Fig. 20. Data table of torque $T^{*}$, speed $\omega$ and current $i_{d}^{*}, i_{q}^{*}$.

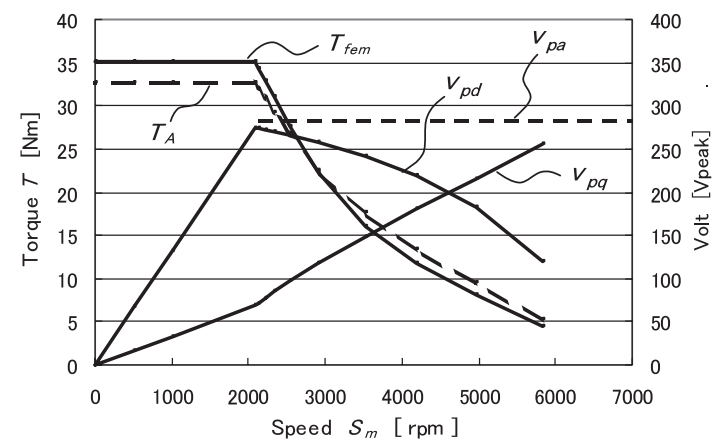

図 21 定出力制御の特性例 (FEM)

Fig. 21. Torque $T$ versus speed $S_{m}$ (FEM).

例として, 図 1(b) の改良電動機について, 回転数 $S_{m}$ が $2,000 \sim 6,000 \mathrm{rpm}$ の時の線間電圧の最大值が $283 \mathrm{~V}$ となる ように電流 $i_{d}, i_{q}$ を計算した例を図 21 に示す。 $v_{p a}$ は 3 相 線間電圧のピーク值で, $v_{p d}$ は $\mathrm{d}$ 軸方向の 3 相線間電圧ピー ク值, $v_{p q}$ は $\mathrm{q}$ 軸方向の 3 相線間電圧ピーク值であり, そ の時の (2) 式によるトルク計算值が $T_{A}$ である。一方，同一 電流条件に抏いて FEM で求めたトルクは $T_{f e m}$ であり, 前 記計算トルク $T_{A}$ がほほ正確に求められていることが確認 できる。そして, $\mathrm{q}$ 軸方向の 3 相電圧ピーク值 $v_{p q}$ は, 回 転数 $\omega$ の上昇と共に無視できない程度に大きな電圧となっ ている様子が良く分かる。

$\langle\mathbf{5} \cdot \mathbf{3}\rangle$ 電圧のフィードフォワード量 $\boldsymbol{F F}_{\boldsymbol{d}}, \boldsymbol{F F}_{\boldsymbol{q}}$, 電流制 御ループゲイン定数 $\boldsymbol{G}_{\boldsymbol{d}}, \boldsymbol{G}_{\boldsymbol{q}}$ の計算法 次に, $\langle 2 \cdot 2\rangle$ 節, 図 3 で示した電圧のフィードフォワード量 $F F_{d}, F F_{q}$ と電 流制御ループゲイン定数 $G_{d}, G_{q}$ の計算方法を示す。

最初に, 〈5·2〉節で求めた電流指令值 $\left(i_{d}, i_{q}\right)$ に抢ける磁 束鎖交数 $\Psi_{d}\left(i_{d}, i_{q}\right), \Psi_{q}\left(i_{d}, i_{q}\right)$ を, 図 17 のデータテーブル から内挿計算して求める。

電圧のフィードフォワード量 $F F_{d}, F F_{q}$ は, (16) 式の電 圧 $v_{d}, v_{q}$ で表され, 求めることができる。

そして, 電流制御ループゲイン定数 $G_{d}, G_{q}$ は, 電流制御 ループの動的なゲインを一定化するための係数であり, 動 作点近傍に扔ける微少範囲のインダクタンスを $L_{r d}, L_{r q}$ と し, 図 17 のデータテーブルの動作点近傍の磁束鎖交数の 微少変化分 $\Delta \Psi_{d}, \Delta \Psi_{q}$ と電流の微少変化分 $\Delta i_{d}, \Delta i_{q}$ を使用 して次式のように求められる。

$$
\begin{aligned}
G_{d} & =L_{r d}=\Delta \Psi_{d} / \Delta i_{d} \\
G_{q} & =L_{r q}=\Delta \Psi_{q} / \Delta i_{q}
\end{aligned}
$$

以上の結果, 図 6 あるいは図 17 のテーブルと (2), (16), (18), (19) 式で, 各電流值 $i_{d}, i_{q}$ における電動機のトルク $T$, 電圧 $v_{d}, v_{q}$ そして動作点近傍におけるインダクタンス $L_{r d}, L_{r q}$ が得られることが示された。そして, 電動機の磁 気非線形性を含めた正確な制御が実現できることになり， 高速応答，高精度な制御が期待できる。

〈5・4 〉磁束鎖交数 $\boldsymbol{\Psi}$ のデータテーブルを使用する電動 機モデルの特徵 以上のことから, この手法の特徽は次 のように言える。

(a) 電動機の特性を正確に表すパラメータは, 動作点のイ ンダクタンスあるいは動作点の磁束鎖交数である。

(b) 非線形で磁気飽和を含む電動機特性は, データテーブ ルを使用して，全動作領域を正確にモデル化できる。その 結果, 正確な磁束デー夕を持つことになり, 高精度で高応 答な制御を実現できる。

(c) FEM デー夕を使用して, 正確かつ容易に前記データ テーブルを作成できる。データテーブルの值は離散的なの で, 各動作点 $\left(i_{d}, i_{q}\right)$ の值は内挿計算して求める。

データテーブルのサイズは, 電流 $i_{d}, i_{q}$ を各 10 ポイント について, 磁束鎖交数 $\Psi_{d}, \Psi_{q}$ を 2 バイトデータとして合 計 400 バイト程度のメモリ容量であり, 全く問題ない。漏 れ磁束 $\Psi_{\text {leak }}$, 鉄損等のその他の制御情報も付加できる。

電動機を制御するマイクロプロセッサの処理時間は，処 理内容が単純なので, 従来と同等あるいは短縮できると推 定される。

(d) 永久磁石を内蔵する電動機についても同じ方法が適 用できる。

(e) 回転子の $d, q$ 軸の方向が曖昧な電動機においても, 座標軸に制約を受けず，正確に表現できる。

(f) また, 電動機の開発段階で, 電動機のより精密な制御 シミュレーションが可能となり, 電動機開発から制御, 負 荷運転までの連成, 連携開発が容易となり, 開発期間短縮 とコスト低減が期待できる。

\section{6. あとがき}

従来の電動機モデルは, 電圧, 電流, インダクタンス, 抵 抗を用いて作られてきた。しかし，磁気的な非線形性，あ るいは, 内蔵する永久磁石などにより電動機が複雑な特性 を示すことが多く，制御上の問題があった。

そこで筆者らは, 有限要素法のデー夕を有効に活用して, 電動機の各動作点における磁束鎖交数を求めてデータテー ブルを作成し，そのデータテーブルを使用して電動機を制 御する方法を提案した。

この方法は, 正確な磁束デー夕を持つため, 電流とトル クの関係だけでなく, 電圧フィードフォワード量の計算, 電流制御ループのゲイン設定を正確に行うことが可能とな り, 高精度で高応答な制御を実現できる。従って, 電動機 
制御において，従来の調整では排除しきれない誤差を低減 でき，また，d，q 軸の磁気的な干渉問題 ${ }^{(7)(12)}$ の低減も可能 である。

(平成 18 年 3 月 13 日受付，平成 18 年 7 月 12 日再受付)
(13) A. Vagati, M. Pastorelli, G. Franceschini, and V. Drogoreanu: "FluxObserver-Based High Performance Control of Synchronous Reluctance Motors by Including Cross Saturation", IEEE Trans. IA, Vol.35, No.3, pp.597605 (1999)

(14) T. Senjyu, A. Omoda, and K. Uezato: "High Efficiency Control of Synchronous Reluctance Motors Using Extended Kalman Filter", IEEE Trans. IES, Vol.50, No.4, pp.726-732 (2003)

\section{文献}

(1) M. Nashiki, A. Satake, Y. kawai, T. Yokochi, and S. Okuma: "Analytical study of flux and experiments of a flux-barrier type reluctance motor with a slit rotor", T. IEE Japan, Vol.116-D, No.6, pp.694-701 (1996-6) (in Japanese)

梨木政行・佐竹明喜 ・ 川井庸市・横地孝典・大熊 繁：「スリット回 転子を用いたフラック $\mathrm{m}$ スバリア型リラクタンスモータの磁界解 析と試作実験」,電学論 D, 116, 6, pp.694-701 (1996-6)

(2) M. Nashiki, A. Satake, Y. kawai, T. Yokochi, and S. Okuma: "Torque Ripple Reduction of Reluctance Motor with Slit Rotor", T. IEE Japan, Vol.117-D, No.8, pp.1008-1014 (1997-8) (in Japanese)

梨木政行・佐竹明喜・川井庸市・横地孝典・大熊 繁：「スリット回 転子を用いたリラクタンスモータのトルクリップル低減法」, 電学論 D, 117, 8, pp.1008-1014 (1997-8)

(3) M. Nashiki, A. Satake, Y. kawai, T. yokochi, and S. Okuma: "A New FluxBarrier-Type Reluctance Motor witha Slit Rotor", IEEE Trans. IES, Vol.46, No.6, pp.1199-1206 (1999-12)

(4) M. Nashiki, Y. Inoue, Y. kawai, T. Yokochi, A. Satake, and S. Okuma: "Improvement of power factor and torque of a synchronous reluctance motor with a slit rotor", IEEJ Trans. IA, Vol.126, No.2, pp.116-123 (2006-2) (in Japanese)

梨木政行 · 井上芳光 · 川井庸市 ·横地孝典 $\cdot$ 佐竹明喜 $\cdot$ 大熊 繁 : 「スリット回転子を用いたシンクロナスリラクタンスモータの力率. トルク向上に関する検討」, 電学論 D, 126, 2, pp.116-123 (2006-2)

(5) N. Matsui and Y. Takeda: "Reluctance Motors-State-of-the-art-", T. IEE Japan, Vol.118-D, No.6, pp.685-690 (1998-6) (in Japanese)

松井信行・武田洋次：「見直されてきたリラクタンスモータ」, 電学 論 D, 118, 6, pp.685-690 (1998-6)

(6) M. Morimoto, N. Matsui, and Y. Takeda: "Recent Advances of Reluctance Motors", T. IEE Japan, Vol.119-D, No.10, pp.1145-1148 (1999-10) (in Japanese)

森本雅之・松井信行・武田洋次：「リラクタンストルク応用電動機の 現状と動向」, 電学論 D, 119, 10, pp.1145-1148 (1999-10)

（7）応用面から見たリラクタンストルク応用電動機の開発動向調查専門 委員会：「応用面から見たリラクタンストルク応用電動機の開発動 向」,電気学会技術報告第 833 号,pp.12-38 (2001)

( 8 ) Y. Honda, S. Kawano, H. Kiriyama, T. Higaki, S. Morimoto, and Y. Takeda: "Rotor Design and Perfomance of a Multi-Flux Barrier Synchronous Reluctance Motor", T. IEE Japan, Vol.118-D, No.10, pp.1177-1184 (1998-10) (in Japanese)

本田幸夫 · 川野慎一朗 - 桐山博之 · 檜垣俊郎 - 森本茂雄 - 武田洋次 : 「マルチフラックスバリア型シンクロナスリラクタンスモータのロー 夕構造と特性比較」, 電学論 D, 118, 10, pp.1177-1184 (1998-10)

(9) Y. Honda, H. Murakami, K. Narazaki, T. Higaki, S. Morimoto, and Y Takeda: "Optimum design of a multi layer interior permanent magnet synchronous motor using reluctance torque", T. IEE Japan, Vol.117-D, No.7, pp.898-904 (1997-7) (in Japanese)

本田幸夫 · 村上 浩 - 楢崎和成 - 檜垣俊郎 - 森本茂雄 - 武田洋次 : 「リラクタンストルクの有効利用をめざした多層埋込磁石構造 PM モータ」, 電学論 D, 117, 7,pp.898-904 (1997-7)

(10) S. Yamamoto and T. Ara: "Detamination of Quadrature Axes Inductances of Reluctance Motors Taking into Account Cross Saturation”, IEEJ Trans. IA, Vol.123, No.8, pp.911-917 (2003-8) (in Japanese)

山本 修・荒 隆裕：「軸間の干渉を考慮したリラクタンスモータの 直軸および横軸インダクタンス算出法」, 電学論 D, 123, 8, pp.911-917 (2003-8)

(11) A. Vagati, M. Pastorelli, A. Canova, and P. Guglielmi: "Design and Control of High Performance Synchronous Reluctance Motors with Multiple-FluxBarrier Rotor", Proc. of IPEC-Tokyo 2000, Vol.1, pp.627-636 (2000)

(12) K. Tobari, T. Endo, Y. Iwaji, and Y. Itou: "Examination of the new vector control system of the permanent magnet synchronous motor for highspeed", IEEJ Industry Application Society Conference, No.1-130, pp.575580 (2003) (in Japanese)

戸張和明 - 遠藤常博 - 岩路善尚 - 伊藤佳樹：「高速用永久磁石同期 モータの新ベクトル制御方式の検討」, H15 電学産業応用部門大会講 演論文集, No.1-130,pp.575-580 (2003)

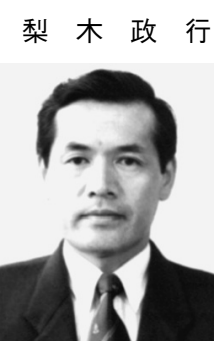

（正員） 1948 年 3 月 24 日生。 1970 年 3 月室蘭 工業大学電気工学科卒業。同年オークマ (株) 入 社。工作機械用サーボモータ，その制御装置，位 置検出器，メカトロニクスに関する開発に従事。 1979 年ブラシレスサーボモータを開発。1993 年 スリット回転子を備えるシンクロナスリラクタン スモー夕を開発。本研究着手後, 2003 年 4 月 (株) デンソーへ入社, 主幹。精密工学会会員。1986 年 度年精密工学会技術賞, 1995 年度精密工学会賞, 1999 年度精密工学 会技術賞を受賞。

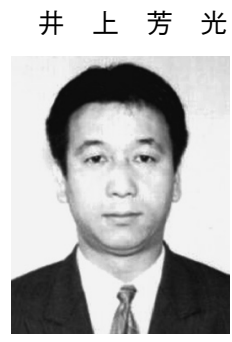

（非会員） 1969 年 9 月 21 日生。 1988 年 3 月岐 阜県立工業高等学校卒業。(株) 平松機械製作所 にて自動車部品生産設備設計。(株) 柏菱エンジ アリングにて航空機構造設計。2001 年オークマ （株）入社。シンクロナスリラクタンスモータ開 発，工作機械設計に従事。

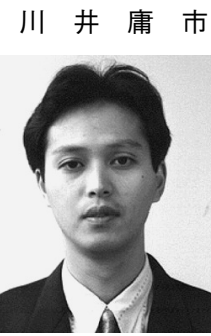

（非会員） 1963 年 12 月 6 日生。 1987 年 3 月福井 大学工学部応用物理学科卒業。同年オークマ (株) 入社。 $\mathrm{CO} 2$ レーザ発振器の開発。現在，リラクタ ンスモータ，リニアモータ，及びメカトロニクス に関する開発に従事。

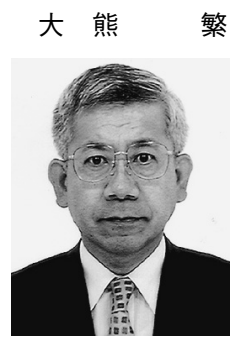

繁（正員） 1948 年 2 月 16 日生。1972 年 3 月名古 屋大学大学院工学研究科修士課程修了。1974 年 6 月ケース・ウェスタン・リザーブ大学大学院修士 課程システム工学専攻修了。1977 年 3 月名古屋 大学大学院博士課程修了。同年 4 月同大学助手, 1979 年 4 月同講師，1984 年 11 月同助教授， 1990 年 12 月同教授，現在に至る。工学博士。主とし て，ロボテイクス，パワーエレクトロニクス，創 発型ソフトコンピュータに関する研究に従事。IEEE, 計測自動制御学 会, 日本ロボット学会, システム制御情報学会, 日本機械学会各会員。 IEEE IECON 論文賞, 精密工学会論文賞, 電気学会論文賞 2 回, ファ ナック FA ロボット財団論文賞をそれぞれ受賞。 